PAEDAGOGIA ChristianA

2/24 (2009) - ISSN 1505-6872

Matgorzata Laskowska*

Warszawa

\title{
Teologiczne podstawy wychowania do galenosfery
}

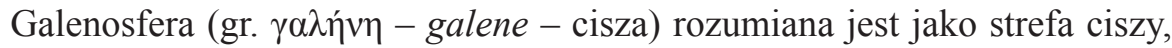
jeden $\mathrm{z}$ istotnych elementów mediosfery. Mediosfera natomiast to przestrzeń medialna człowieka, na którą składa się - oprócz wymienionej wyżej galenosfery - także ikonosfera (środowisko obrazu), logosfera (środowisko słowa), sonosfera (środowisko dźwięku). Strefy te - główne centra rozwoju osobowego człowieka - wymagają głębszego studium, zwłaszcza galenosfera, która jest „,najmniejszą częścią" w mediosferze ludzkiej ${ }^{1}$. Stąd też skromny wykaz publikacji na jej temat. Wynika to także z trudności, jakie stwarzają badania nad ciszą. Cennym wkładem w naukową refleksję o galenosferze człowieka jest odszukanie jej teologiczno-pedagogicznych, w tym także biblijnych odniesień. Niniejszy artykuł zostanie poświęcony temu zagadnieniu.

\section{Stan współczesnej mediosfery człowieka}

Komputer do tego stopnia zdominował XXI wiek, że pojawiła się propozycja, by moment jego pojawienia się na rynku elektronicznym traktować jako wyznacznik początku prawdziwych dziejów ludzkości - B.C. miałoby odtąd oznaczać nie before Christ, lecz before computers ${ }^{2}$. Pojawienie się komputera zapoczątkowało życie w „stałym łączu” - funkcjonowanie online, teleobecność. Era komputera nadała nowy charakter instytucjom publicznym (pojawiły się poradnie wirtualne, TV interaktywna, nowe metody uczenia się w postaci

* Dr Małgorzata Laskowska, doktor teologii środków społecznego przekazu.

1 A. Lepa, Funkcja logosfery w wychowaniu do mediów, Łódź 2006, s. 104-105.

2 Por. W. J. Burszta, Internetowa polis w trzech krótkich odstonach, w: tenże (red.), Po co nam rzeczywistość? Ekran - mit-rzeczywistość, Warszawa 2003, s. 171. 
e-learning). Zmiany zaszły również we wzajemnym komunikowaniu się. Wszelkie komunikatory (gadu-gadu, skype, telefony komórkowe, maile) wzbogacone obrazem mają ułatwiać kontakty prywatne i zawodowe. Za pomocą Internetu można przeprowadzić np. telekonferencję z udziałem ludzi z różnych stron świata. Stąd też wielu „współczesnym młodym (z reguły) mieszkańcom wirtualnych światów jakże dziwne wydaje się życie ich rodziców i dziadków, skazanych na czarno-białą telewizję z jednym programem, jeden aparat telefoniczny ustawiony w jadalnym pokoju i opasłe tomy encyklopedii, które tak długo trzeba kartkować"3. Każda dziedzina życia unowocześnia się. Nauka języka, tańca, znalezienie pracy, zdobycie potrzebnych informacji, wysłanie listu, zrobienie przelewu bankowego dokonuje się o wiele szybciej.

Trudno jednak żyć w pełnym i bezkrytycznym zachwycie nad nową technologia. Społeczeństwo offline dotyka kryzys. „Wylogowany” człowiek, a raczej „użytkownik”, czuje się bardziej zagubiony. Nie ma on trudności w cyberprzestrzeni, bo w niej jest odważny, otwarty, pewny siebie i profesjonalny. Ma je natomiast w realnym świecie, kiedy musi przeprowadzić konwersację, przeczytać grubą książkę czy zwyczajnie posiedzieć w ciszy.

Szybki rozwój techniki, bezkrytyczny jej odbiór lub brak umiejętności dawkowania jej prowadzą zatem do zaburzeń w mediosferze ludzkiej - logosferze, sonosferze, ikonosferze, a zwłaszcza w galenosferze. Poniżej zostaną pokrótce omówione niepokojące zjawiska, dotykające te przestrzenie.

W obecnym kontekście kulturowym zauważa się marginalizację logosfery ${ }^{4}$. Proces ten postępuje w wyniku dynamicznego rozwoju ikonosfery ${ }^{5}$. Film, gry komputerowe, komiks, prasa ilustrowana, silnie oddziaływujące na wzrok człowieka, cieszą się większym powodzeniem niż słowo drukowane. Stąd też lektury szkolne, by nadal miały odbiorcę, przedstawia się za pomocą komiksu lub obrazu filmowego. Zjawisko to pokazuje, że społeczeństwo wraca mentalnie do czasów Biblia pauperum ${ }^{6}$. Ten średniowieczny przekaz staje się symbolem XXI wieku, określa kulturę, bazująca głównie na obrazie ${ }^{7}$. Mimo że dzisiaj każdy potrafi czytać, coraz bardziej zauważa się świadomą rezygnację z tego przywileju,

3 Tamże, s. 157.

${ }^{4}$ Zob. A. Lepa, Logosfera, „Łódzkie Studia Teologiczne” 4 (1995), s. 197-202.

${ }^{5}$ Por. tenże, Pedagogika mass mediów, Łódź 2003, s. 181-184; tenże, Funkcja, s. 54-90.

${ }^{6}$ Biblia Pauperum to dokładnie ilustrowana książka, przedstawiająca sceny biblijne Starego i Nowego Testamentu. Do dzisiaj trwa spór, czy rzeczywiście Biblia pauperum powstała wyłącznie na potrzeby analfabetów. W prezentowanym artykule zastosowano skrót myślowy w celu lepszego zobrazowania bolączki współczesnej kultury. Autor nie chce wnikać, kto rzeczywiście był odbiorcą tego średniowiecznego przekazu. Więcej na ten temat w: Biblia pauperum, w: Nowa Encyklopedia Powszechna PWN, t. 2, Warszawa 1995, s. 449; Biblia pauperum, w: Encyklopedia wiedzy o ksiażce, Wrocław-Warszawa-Kraków 1971, kol. 144-146; R. Knapiński, Biblia Pauperum-Czy rzeczywiście księga ubogich duchem?, „Roczniki Humanistyczne” 2 (2000), s. 223-245.

7 Por. M. Sznajderman, Wspótczesna „Biblia pauperum”. Szkice o wideo i kulturze popularnej, Kraków 1998. 
co prowadzi do wtórnego analfabetyzmu. Dorośli mają problem z wysławianiem się, wyrażaniem myśli, rozumieniem czytanego tekstu, formułowaniem krótkiego przekazu.

Kryzys dosięga nie tylko strefę słowa, ale także dźwięku. Przykładem tego jest spadek zainteresowania słuchowiskami radiowymi, które rozwijają nie tylko wyobraźnię, ale także zdolność słuchania i koncentracji. Niektórzy badacze twierdza, że radio zaspokaja wszystkie potrzeby wymienione w hierarchii Abrahama Maslowa. Są to przede wszystkim te podstawowe - fizjologiczne, będąc dobrym „towarzyszem” w odpoczynku. Oprócz tego ramówka radia jest dostosowana do biologicznego rytmu człowieka - intensywniejszy i bardziej urozmaicony program proponowany jest w dzień, a w nocy mniej angażujący, wiosną pojawia się więcej programów ogrodniczych, a zimą prognoz pogody i informacji turystycznych. Radio zaspokaja także potrzebę bezpieczeństwa, dostarczając słuchaczowi codziennie informacje: od warunków w ruchu drogowym aż po sytuację militarną w kraju i na świecie. W czasie wojny słuchacz mniej więcej wie, które rejony są zagrożone, jak należy się zachować, co robić, a w czasie pokoju słyszy zapewnienie, że nic narodowemu bezpieczeństwu nie zagraża. Kolejną potrzebą, jaką radio po części zaspokaja, jest potrzeba miłości i przynależności. Człowiek, który przebywa sam w pomieszczeniu, czy po prostu żyje samotnie, słucha znacznie więcej audycji radiowych, co zmniejsza jego odczucie izolacji. Dodatkowo ma wrażenie, że jest częścią zbiorowości, biorąc pod uwagę, że tej samej audycji słuchają tysiące ludzi. Poczucie przynależności wzmacnia także możliwość połączenia się telefonicznego ze studiem i z innymi odbiorcami, co tworzy swego rodzaju więź i przywiązanie oraz zaspokaja kolejną potrzebę w hierarchii Maslowa - potrzebę szacunku i uznania. Radio, poprzez dostarczanie konkretnej wiedzy, muzyki, podsuwa tematy do konwersacji, daje możliwości bycia poinformowanym, zorientowanym, co wzmacnia poczucie własnej wartości, zaspokaja potrzebę bycia uznanym i kompetentnym. A to także duży impuls do zaspokojenia kolejnej - najwyższej w hierarchii Maslowa - potrzeby samorealizacji ${ }^{8}$. Radio traci jednak obecnie na popularności. Największym powodzeniem cieszą się te stacje, które oferują przede wszystkim muzykę.

Zagrożenia, jakie dotykają logosferę i sonosferę, mają także wpływ na galenosferę. Strefa ciszy wydaje się najsłabiej rozwinięta u współczesnego człowieka ${ }^{9}$. Cisza jest zjawiskiem trudnym do zdefiniowania i zbadania, zwłaszcza w kontekście mediosfery. O wiele łatwiej zrozumieć ją w świecie przyrody, gdzie rozumiana jest jako stan spoczynku lub zapowiedź zbliżającego się niebez-

${ }^{8}$ Por. M. W. Shanahan, N. Brown, Radio Listening as a Function of Basic Human Need: Why did Maslow listen to radio?, „Journal of Media Psychology” 10 (2002), online: http://www. calstatela.edu/faculty/sfischo/maslow.html (12.07.2009).

9 Wniosek taki pojawia się chociażby po stwierdzeniu, że cisza - jako element mediosfery nie jest wystarczająco opracowana w pedagogice i medioznastwie. Dotyczy to także ciszy rozumianej jako podstawowy składnik codziennego funkcjonowania społecznego, twórczości artystycznej (muzyka, poezja śpiewana, recytowana itp.). 
pieczeństwa. Można jedynie określić, że na galenosferę ludzką składa się cisza i milczenie, które towarzyszą na przykład osobie czytającej książkę czy piszącej list. Myślenie jest jednak także elementem logosfery, a to oznacza, że nie można galenosfery analizować w oderwaniu od logosfery, ikonosfery i sonosfery.

Każdy człowiek, w zależności od charakteru, zainteresowań, warunków zewnętrznych, ma inną mediosferę. Jeden ma bardziej rozwiniętą sferę słowa, inny - obrazu lub dźwięku. Wśród badanych 100 osób w grupie wiekowej 20-25 lat $70 \%$ osób ciszę pojmuje jako element relaksu, odpoczynku, a 10\% - jako nudę i monotonię ${ }^{10}$. Dane te ukazuja, że (przynajmniej w tej grupie wiekowej) dla jednych cisza jest twórcza, pożądana, poszukiwana, ale dla innych wręcz przeciwnie - niechciana.

Słabo rozwinięta galenosfera wpływa negatywnie na pozostałe składniki mediosfery: ikonosferę, sonosferę i logosferę. Oto niektóre skutki zaburzania i lekceważenia ciszy:

a) w odniesieniu do mediosfery:

- zbyt duże „dawkowanie” obrazu (na przykład częste oglądanie telewizji), dźwięku (na przykład uzależnienie od głośnej muzyki), słowa (na przykład skłonność do gadulstwa, rozmowa przy włączonym odbiorniku telewizyjnym, radiowym);

- bezkrytyczność w odbiorze przekazu medialnego - gdy w mediosferze cisza jest marginalizowana, odbiorca pozbawiony jest warunków do refleksji nad treścią przekazu - ten typ odbiorcy narażony jest na uzależnienie od mediów;

- brak odporności na propagandę, reklamę;

- wysoka skłonność do konsumizmu medialnego ${ }^{11}$;

b) pod względem psychologicznym:

- lęk przed cisza, wynikający z przekonania, że w ciszy nic się nie dzieje $^{12}$;

${ }^{10}$ Por. I. Jędrzejewska, Definicja a znaczenie - czyli jak ustyszeć i zrozumieć ciszę, „Tematy z Szewskiej" 1 (2007), s. 24.

${ }^{11}$ Por. A. Lepa, Media a postawy, Łódź 2003, s. 89-91; S. van Calster, Czy telewizja izoluje człowieka? Konsumpcja zamiast komunikacji, „Communio” 6 (1995), s. 44-53; M. Laskowska, Wspótczesne mity na temat szczęścia, czyli wpływ mediów na jego postrzeganie, Kolekcja „Communio" 18 (2008), s. 170.

12 „Jawi się nam zatem cisza jako coś bardzo niezdeterminowanego, jako bezruch i bezład, a właściwie tylko bez-ruch i bez-czas. Cisza jednakże przenosi się na inne zmysły. Jest przecież tak, że odczuwamy ją jako napięcie i drżenie; wówczas dzieje się coś w całym człowieku, jest on bowiem jednością psychofizyczną, tak, że cisza może stać się stanem nieznośnym. Brak reakcji jednego ze zmysłów powoduje zaniepokojenie wszystkich pozostałych. Tak właśnie odbiera człowiek «ciszę przed burzą». Całym sobą okazuje zaniepokojenie i naprężenie w oczekiwaniu tego, co ma się wydarzyć. Cisza jest więc stanem niepożądanym, napiętnowanym i przeklętym, jest bowiem brakiem i niedostatkiem. [...] Człowiek [...] jeśli zatem nie odczuje i nie zarejestruje dźwięku, który - jako ta fala - pójdzie w postaci impulsu elektronicznego po jego neuronach, to ludzki duch odbierze jako stagnację i wręcz nicość. Dźwięk bowiem przynależy człowiekowi i jeśli nie ma ma- 
- lęk przed samotnością, zapomnieniem;

- nadpobudliwość (reakcją na ciszę, dłuższą pauzę w wypowiedzi może być złość, agresja);

- bezrefleksyjność;

- chaos i niedojrzałość emocjonalna;

- podatność na stres;

- brak kontaktu z samym sobą, nieznajomość swoich potrzeb;

c) pod względem społecznym:

- zaburzenia w komunikacji (gadatliwość, brak wzajemnego zrozumienia);

- pęd za aktywnością (dźwiękiem, słowem, obrazem) burzy harmonię całej mediosfery;

- skłonności do impulsywności w relacji;

- lęk przed niedocenianiem, przed rutyna, przyzwyczajeniem, codziennością.

Warto zastanowić się nad przyczynami kryzysu, jaki dosięga galenosferę. Skąd pochodzą trudności człowieka z pielęgnowaniem ciszy? W kolejnym punkcie przyjrzymy się, co Biblia mówi na temat galenosfery człowieka i jakie wnioski o charakterze pedagogicznym można wyprowadzić z jej lektury.

\section{2. „Biblijna” galenosfera}

Tradycja i Biblia zawierają afirmację milczenia i ciszy. Przede wszystkim były one wyrazem czci i szacunku względem wielkości i doniosłości Boga. Jego Imię jest tak święte, że wymaga „ciszy miłującej adoracji” (por. KKK 2143). Rozumiał to Abraham, który jako „,złowiek milczenia, w tych miejscach, gdzie się zatrzymuje, buduje ołtarz dla Pana. Dopiero później pojawia się jego pierwsza modlitwa wyrażona w słowach" (por. KKK 2570; Rdz 15, 2-3). Adoracyjne i pokorne milczenie względem potęgi Najwyższego przenikało także modlitwę paralityka (Mk 2, 5), błagający dotyk kobiety cierpiącej na krwotok (Mk 5, 28), płacz Magdaleny (Łk 7, 37-38; por. KKK 2616). Chrześcijaństwo traktowało milczenie jako szczególnie skuteczną drogę doskonalenia. Jedna z zakonnych sentencji brzmi: Taciturnitas virtutes plurimas nutrit - „milczeniem karmią się wszystkie cnoty”"13. Milcząca modlitwa, zwana kontemplacyjną, określana jest jako „milcząca miłość" (por. KKK 2717). Dowodzi to temu, że najbardziej intymne chwile ludzkiego życia (rozmowa z Bogiem, także z człowiekiem) odbywają się w ciszy

terii lub jest jej bezruch [...], to nie ma człowieka”. J. Czarny, Cicho-sza, niczego nie ma, „Tematy z Szewskiej" 1 (2007), s. 22.

${ }^{13}$ Por. L. Moulin, Życie codziennie zakonników w średniowieczu (X-XV wiek), Tyniec 1979, cyt. za M. Stępień, Obrazy milczenia - milczenie obrazów. O mowie i milczeniu w sztuce dawnej i współczesnej, w: K. Handke (red.), Semantyka milczenia, Warszawa 1999, s. 49. 
i milczeniu. Są one tak silnie osadzone w mistyce, że św. Jan od Krzyża ciszę traktował jako synonim języka boskiego ${ }^{14}$.

Afirmacja ciszy widoczna jest także w sztuce sakralnej, zawierającej XIII-, XIV- i XVI-wieczny motyw Sacra converatione, w obrazach na przykład: Giovanniego Belliniego, Giorgiona, Tycjana i Veronese'a. Przedstawiają one poszczególnych świętych skupionych wokół tronu Matki Bożej. Zauważalne jest na nich milczenie ${ }^{15}$. Tłumaczy je etymologia słowa converatio, które nie tyle oznacza rozmowę, ale po prostu „obcowanie, przebywanie" ${ }^{16}$.

Spośród teologicznej spuścizny piśmienniczej najbardziej bogatą w refleksje na temat ciszy jest Biblia. Jej różnorodność zjawisk, sytuacji i postaw wyłania ciekawe wnioski, także o charakterze pedagogicznym, na temat galenosfery człowieka. Na wstępie tej analizy należy jednak postawić pytania: czy uzasadnione jest używanie sformułowania: „biblijna galenosfera”?; czy istnieje takie zjawisko, jak „biblijna mediosfera”?

Mediosfera człowieka nie istnieje od momentu pojawienia się tradycyjnych środków społecznego przekazu, ale od pojawienia się człowieka, czyli jego umiejętności komunikowania - mówienia (logosfera), słuchania, tworzenia dźwięków (sonosfera), obrazów (ikonosfera) i wreszcie - funkcjonowania (najczęściej nieświadomego) w ciszy (galenosfera). Analiza tego zjawiska w kontekście złożoności zjawisk, wydarzeń, postaw obecnych w Biblii, jest dosyć złożona. Stąd też w opracowaniu tym ograniczono się do galenosfery świętej Rodziny, czyli do Maryi, Józefa i Jezusa.

W pierwszej kolejności należałoby omówić Nazaret, czyli „miasto rodzinne” Jezusa (Mt 13, 54; Łk 4, 16). Święta Rodzina przeżywała tu decydujące chwile swojego życia. Miały tu miejsce wydarzenia-ikony chrześcijaństwa (na przykład Zwiastowanie). W tradycji chrześcijańskiej Nazaret staje się symbolem ciszy, milczenia, ubóstwa, skromności i świętości. Stąd też w duchowości chrześcijańskiej miejsce to jest symbolem przygotowania się do doskonalszej służby Bogu, życia ubogiego, wyzbycia się własnego ,ja” dla ściślejszego zjednoczenia się z Bogiem. Wielu świętych podążało tą drogą. Przykładem jest bł. Karol de Foucauld, który - dosłownie rozumiejąc - udał się na trzy lata do Nazaretu, by tam odczytać powołanie do kapłaństwa ${ }^{17}$.

${ }^{14}$ Por. M. Krupa, Cisza mistycznej kontemplacji. Milczenie Pieśni duchowej św. Jana od Krzyża i jej polskich przektadów, „Tematy z Szewskiej” 1 (2007), s. 48.

${ }^{15}$ Por. M. Stępień, dz. cyt., s. 99-100.

${ }^{16}$ Ciszę i milczenie znała także sztuka niechrześcijańska. Szczególnie ukazane były one w Mezopotamii, Egipcie, a także w Grecji, gdzie przez pierwsze tysiąclecia dziejów sztuki nie było osób mówiących. Jest w niej obecny raczej język pozawerbalny (mowa ciała, mimika twarzy). Motyw otwartych ust pojawił się dopiero w V wieku p.n.e. (np. widoczne jest to w „Niobidka”; „Leżący Niobida"). Cisza i milczenie ukazane są m.in. w obrazach Gerarda Dou, Pietera de Hoocha, Gerarda Terborcha, Caspara Netschera, ale także Rembrandta van Rinn i Jana Vermeera van Delft.

${ }^{17}$ Zob. J. Umerle, Nazaret wedlug Karola de Foucauld: duchowość nazaretańska w świetle 
Szczególną postacią „Miasta Ciszy” jest Maryja. Na podstawie Biblii oraz Tradycji Kościoła można wywnioskować, że jest Ona osobą o bardzo dojrzałej galenosferze. Świadczy o tym już Jej postawa i usposobienie. Ewangelista Łukasz podaje, że „wszystko chowała w swoim sercu” (Łk 2, 19). Ciszę i milczenie traktowała jako sacrum, czyli świętość, której nie godzi się zakłócać chaosem myśli i języka. W niej słowo dojrzewało. Cisza stanowi schronienie dla myśli, najważniejszych decyzji. Stwarza warunki do dialogu z Bogiem. Cisza w Maryi jest również wtedy dostrzegalna, gdy krząta się, troszcząc o innych, na przykład na weselu w Kanie.

Dojrzałość galenosfery Maryi sprawia, że Jej logosfera jest również taka

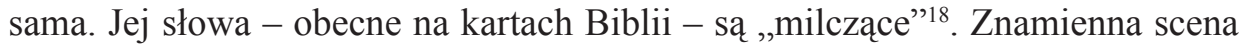
Zwiastowania wskazuje, że wyłącznie człowiek ciszy jest skłonny do dialogu z aniołem, dosłyszy i zrozumie, wyzbędzie się lęku i zacznie rozmawiać: „Jakże się to stanie, skoro nie znam męża?”. Z dojrzałej ciszy rodzi się pełna i świadoma odpowiedź: „Na to rzekła Maryja: Oto Ja służebnica Pańska, niech Mi się stanie według twego słowa!" (Łk 1, 34. 38). Ta odpowiedź ufności i zawierzenia zrodziła się pod wpływem pełnego milczenia i słuchania anioła. Ten Jej wyjaśniał, jak „to się stanie”. Ona wtedy rzeczywiście milczy i słucha.

Galenosferę Maryi przybliża także jej podróż do Elżbiety. Droga wiedzie przez góry (por. Łk 1, 39). Trasa ta - górzysta, długa - wręcz zmuszała do długiego trwania w ciszy, mimo że podróż odbywa się w pośpiechu. Kontakt z przyrodą rozwija w człowieku umiejętność trwania w ciszy. W tym samym rozdziale Ewangelii św. Łukasza Maryja modli się: „Wielbi dusza moja Pana...” (Łk 1, 46). Jak już wcześniej zostało to ukazane, medytacja, rozmowa z Bogiem, to szczególny „egzamin” dla galenosfery. Czas ten - w Jej przypadku - ukazuje pełnię dojrzałości. Potwierdzają to także słowa: ,zachowywała wszystkie te sprawy i rozważała je w swoim sercu" (Łk 2, 19). Współczesna moda daleka jest od propagowania takich postaw. Środki społecznego przekazu promują niczym nieskrępowaną otwartość. Ten, który niewiele mówi o sobie, traktowany jest jak obcy, inny, czasem nawet pyszny.

Warto zatrzymać się także nad innymi słowami Maryi: „Synu, czemuś nam to uczynił?” (Łk 2, 48). Maryja nie rozumie odpowiedzi Jezusa, ale nie dopytuje więcej o szczegóły, zachowuje tajemnicę Jezusa, która wielokrotnie sprawia Jej ból w sercu. Kolejny dowód dojrzałości maryjnej logosfery i galenosfery związany jest z weselem w Kanie. Gdy informuje, że „nie mają już wina” (J 2, 3), słyszy: „Jeszcze nie nadeszła godzina moja”, po czym reaguje milczącą i pełną ufności odpowiedzią: „Zróbcie wszystko, cokolwiek wam powie” (w. 5).

Słowa te wynikają z milczenia i zmierzają do milczenia pełnego, ostatecznego, nadprzyrodzonego, boskiego - ścisłego zjednoczenia się z milczeniem Jezusa na krzyżu. Wówczas galenosfera Maryi wystawiona zostaje na próbę. W godzinie

życia i pism Karola de Foucauld, Włocławek 2006; A. Mandonico, Nazaret: un luogo, un simbolo, un'esperienza nella spiritualita'di Charles de Foucauld (1858-1916), Roma 2001.

${ }^{18}$ M. M. de Carvalho, Milczenie Maryi, „Communio” 1 (2005), s. 51. 
konania Jezusa, w czasie długiej Męki, nie podbiega, jak Weronika, nie pomaga, jak Cyrenejczyk, ale milczy rozmodlona z boku. Milczenie Maryi pokrywa się z wolą Bożą, która dokonuje się przez Syna i w Synu. Cierpienie z milczeniem są sobie pokrewne. Męczeństwo dokonuje się i dojrzewa właśnie w ciszy. Towarzyszyć mu może zewnętrzny hałas, lecz doświadczenie bólu niedostępne jest dla świata zewnętrznego. I ono jest dużym sprawdzianem dla galenosfery człowieka. Im bardziej jest ona rozwinięta, tym cierpienie jest przyjmowane $\mathrm{z}$ większą odwagą i szlachetnością.

Analiza galenosfery Maryi podsuwa pod refleksję kwestię samotności, która „uczestniczy w rzeczywistości milczenia”" ${ }^{19}$. Zwolenników samotności w żadnej kulturze i religii nie brakuje. Jednym z największych był św. Jan od Krzyża: „posiadał jedną pasję, którą można było z łatwością dostrzec: zamiłowanie do samotności; potrzebę przebywania w ciszy i osamotnieniu. Jego miłość do samotności «była zwykłą raną, lecz taka, która pozostawia bliznę; klauzurą przynoszącą owoce i pozwalającą na odnalezienie samego siebie; miejscem skupienia i refleksji». [...] Jego samotność była czymś w rodzaju cięciwy rozciągniętej pomiędzy psychicznym cierpieniem a kreatywnością"20. Ta postawa nie zawsze spotykała się ze zrozumieniem, aczkolwiek wielokrotnie wiąże się ze świadomie obraną posługą dla Kościoła ${ }^{21}$.

Badając galenosferę Nazaretu, nie sposób pominąć przestrzeń ciszy św. Józefa, małżonka Maryi (Łk 1, 27). Ponieważ jego rola jest nieco inna niż Maryi, jego wewnętrzny świat również. Z zawodu stolarz, żywiciel rodziny, często pogrążony w pracy i modlitwie musiał mieć dobrze uformowaną galenosferę ${ }^{22}$. Sfera ciszy silnie osadzona w Bogu sprawiała, że był prawdziwym oparciem dla Jezusa i Maryi. Bóg jest jego pełnią. W jego przypadku można zauważyć, że cisza jest niejako jego powołaniem. Obok jego dojrzałej galenosfery rozwija się Logos. Św. Józef ustępuje miejsca woli Bożej, która objawia się w Jezusie - Synu Bożym i Synu Maryi, która ma być nie tylko matką ziemską, nazaretańską, ale także całej ludzkości. Jego postać jest symbolem milczenia, pokory, lecz - jak zauważa Jan Paweł II w adhortacji apostolskiej o św. Józefie Redemptoris custos - „milczenie Józefa ma swą szczególną wymowę: poprzez to milczenie można w pełni odczytać prawdę, jaką zawiera ewangeliczne stwierdzenie: „mąż sprawiedliwy" (por. Mt 1, 19)" (nr 17).

Milczenie to równocześnie w sposób szczególny odsłania wewnętrzny profil tej postaci. Ewangelie mówią wyłącznie o tym, co Józef „uczynił”. Jednakże w tych osłoniętych milczeniem ,uczynkach” Józefa pozwalają odkryć klimat głę-

${ }^{19}$ Por. K. T. Wencel, Pedagogia milczenia, „Paedagogia Christiana” 1/13 (2004), s. 47.

${ }^{20}$ M. Krupa, dz. cyt., s. 50; R. Rossi, Juan de la Cruz. Silencio y creatividad, Madrid 1996, s. $42-43$.

${ }^{21}$ Więcej na temat samotności św. Jana od Krzyża oraz w jego spojrzenia na ten stan w: http://communiocrucis.pl/index.php?option=com_content\&task=view\&id=212\&Itemid $=65$ (12.07.2009).

${ }^{22}$ Por. L. Balter, Cicha obecność Józefa, „Communio” 1 (2005), s. 56-65. 
bokiej kontemplacji: Józef obcował na co dzień z tajemnicą „od wieków ukrytą w Bogu”, która „zamieszkała” pod dachem jego domu. Można zrozumieć, dlaczego św. Teresa od Jezusa, wielka reformatorka kontemplacyjnego Karmelu, stała się szczególną odnowicielką kultu św. Józefa w zachodnim chrześcijaństwie (RC 25).

Ważną lekcją dla galenosfery człowieka współczesnego jest „ukryte życie” Jezusa. Należy je rozumieć symbolicznie jako lata przygotowania, dorastania Jezusa do przyszłej mesjańskiej misji. Jezus prowadzi w Nazarecie, jak podaja fragmenty z tamtego okresu, życie proste, skupione na pracy i modlitwie. Analizując całe jego życie, ten czas można określić „,ciszą”. To było „milczenie zwyczajnego życia" (por. KKK 132). Związane ono było ściśle z rodziną i pracą (por. KKK 533). Z Ewangelii można wyczytać na temat tego okresu życia Jezusa, że czynił on ,ppostępy w mądrości, w latach i w łasce u Boga i u ludzi” (Łk 2, 52). Czas ten poprzedza kolejny etap życia Jezusa - nauczanie i mękę, stąd też nie jest czasem straconym, lecz - jak się okazuje - niezastąpionym w owocnym wypełnianiu misji ${ }^{23}$. Cisza jest zatem zapowiedzią wypełnienia Słowa.

\section{Pedagogia galenosfery - wychowanie do ciszy}

Pismo święte podaje, że ludzie cisi są szczęśliwi, błogosławieni (Mt 5, 5). Na przykładzie galenosfery Nazaretu można dostrzec, jak znaczący wkład ma ona w kształtowanie osobowości. Jej analiza pozwala wyciagnąć istotne wnioski dla współczesnej mediosfery, cenne zwłaszcza dla pedagogów, wychowawców, rodziców, ale i dla każdego, kto chce popracować nad dojrzałością własnej galenosfery.

W pierwszej kolejności należy zwrócić uwagę na „ukryte” życie Jezusa. Skoro Bóg-człowiek przyzwala na taki czas, wydawałoby się stracony, to musi kryć się w tym większy sens. Okres przygotowania się Jezusa do wypełnienia misji ukazuje, że każdy do takiego czasu ma prawo - zarówno dziecko, jak i dorosły. Psychologicznie interpretując ten czas, może to być okres dzieciństwa, dojrzewania, podczas którego młody człowiek korzysta z tego przywileju, że jest jeszcze „niegotowy” w pełni do dorosłego życia - bawi się i uczy. Jakże krzywdzące jest odzieranie wychowana z przywileju „ukrytego życia”, wypełniając je różnego rodzaju kursami, zajęciami i warsztatami. Poprzez wrzucanie dziecka w wir wielu zobowiązań, traci ono dzieciństwo, potem młodość. Trudno się zatem dziwić, gdy w wieku trzydziestu lat często doświadcza zawodowego

${ }^{23}$ Zob. G. DeRosa, Gli anni oscuri di Gesù a Nazaret: la giovinezza di Gesù, „La Civiltà Cattolica” 159 (2008), s. 433-444; P. Góralczyk, Życie ukryte, ale w wolności, „Communio” 1 (2005), s. 116-124; T. Stramare, Tajemnica życia ukrytego Jezusa w centrum teologii „Redemptoris Custos”, „Kaliskie Studia Teologiczne” 4 (2005), 35-47; J. C. O’Neil, The Silence of Jesus, „New Testament Studies” 2 (1969), 153-167. 
wypalenia - apatii, zniechęcenia, ciaggego napięcia i rywalizacji. Życie Jezusa ukazuje, że każdy ma prawo do ciszy, rozumianej dosłownie, jak i w kontekście zawodowej aktywności. Ta „cisza” w życiorysie - przebywanie z dala od zgiełku, publiczności - może być rzeczywiście współcześnie niezrozumiana. Urlop wypoczynkowy, choroba czy macierzyństwo jawi się niektórym po prostu jako czas „nieobecności w pracy”, czyli brak możliwości wykazania się, a nawet jako przerwa w rozwoju. Owo biblijne, symboliczne ,życie w ukryciu” jest zatem często uważane za czas stracony ${ }^{24}$. Wśród badanych młodych Amerykanów dwie trzecie pragnie być gwiazda, chce być zauważonym, najlepiej w mediach ${ }^{25}$. Owe zjawisko można określić teorią tzw. pięciu minut. Takie myślenie i postępowanie wynika z przekonania, że tego, czego nie ma w telewizji (czy po prostu w środkach społecznego przekazu), nie ma w rzeczywistości - to nie istnieje, „wydaje się pozbawione znaczenia"²6. Życie Jezusa pokazuje jednak inną prawidłowość. Właśnie w ciszy Jezus przygotowywał się do wielkiej misji, do zadań ważnych na skalę światową o charakterze ponaddoczesnym.

Cisza, jak ukazano powyżej, ma wymiar nadprzyrodzony i stanowi niezbędny element integralnego rozwoju człowieka - sfery ducha, ciała i psychiki. W niej Jezus dorastał do przyjęcia woli Bożej, tym samym podobny proces powinien dokonywać się w życiu Jego uczniów. Każdy człowiek potrzebuje ciszy, wielu momentów odejścia, by zrozumieć, do jakiego zawodu ma predyspozycje, jakie jest jego powołanie itd ${ }^{27}$. W ciszy Maryja dojrzewała do cierpienia. Jednocześnie milczenie było Jej odpowiedzią, zgodą na to trudne wydarzenia w życiu Jej syna. Gdy od najmłodszych lat człowiek nauczy się poszanowania ciszy, odkryje jej walory, w momentach bólu i rozterki znajdzie w niej siłę, a także odpowiedzi na trudne pytania. Sfera ciszy będzie jego przestrzenią niedostępną dla innych. Bycie sam na sam ze sobą nie należy jednak do prostych umiejętności. Zaleca się zatem częste przebywanie w samotności, by bardziej poznać swoje myśli, pragnienia, by nawiązać ze sobą kontakt. Z czasem zaowocuje to zdolnością do skupienia, opanowania się, milczenia, ograniczania się w nadmiernym i zbędnym mówieniu.

W tym wszystkim ujawnia się kolejna wartość galenosfery. W niej dokonuje się nie tylko dojrzewanie fizyczne i psychiczne, ale także duchowe. Stanowi ona bowiem doskonałe podłoże do doświadczenia i spotkania z Bogiem. Duchowy wzrost w dużej mierze zależy od dojrzałości galenosfery. Przykład świętej Rodzi-

\footnotetext{
${ }^{24}$ Por. R. Brague, Czas stracony?, „Communio” 1 (2005), s. 3-10.

${ }^{25}$ Por. J. Naisbitt, N. Naisbitt, D. Philips, High Tech - High touch. Technologia a poszukiwanie sensu, Poznań 2003, s. 111-117.

${ }^{26}$ Instrukcja duszpasterska Aetatis novae, nr 4. To zjawisko może mieć poważne konsekwencje dla wartości chrześcijańskich. Jak słusznie zauważono w cytowanym dokumencie: „W ten sposób jednostki i grupy, o których nie mówi się w środkach przekazu, mogą być de facto zmuszone do milczenia; nawet głos Ewangelii może zostać w ten sposób przytłumiony chociaż nie całkiem zagłuszony" (AN 4).

${ }^{27}$ Por. K. T. Wencel, dz. cyt, s. 49-50.
} 
ny ukazuje, że autentyczna relacja z Bogiem zapewnia cenne wartości nadprzyrodzone: pokorę, pokój wewnętrzny, miłość, dobroć, mądrość.

Cisza bierze także udział w rozwoju społecznym człowieka. Dobre relacje międzyludzkie zależą od tego, jaką każdy z rozmówców posiada galenosferę. Cisza stwarza bowiem dogodne warunki do słuchania. Oznaką słuchania jest milczenie, czyli stały element każdej konwersacji. Przerwane czy zakłócone milczenie może zaburzyć przekaz słowny. Milczenie obecne jest tak w dialogu, tak i w monologu. Przykładem są przemówienia. Świadome używanie mowy czy przemilczanie są stałym elementem retoryki. Jak zaznaczali sofiści, retor wie: „co kiedy powiedzieć, a co przemilczeć" 28 .

Inną ważną funkcją galenosfery jest jej aktywny udział w rozwoju intelektualnym człowieka - w ,,posłudze myślenia”, jak to wyraził Jan Paweł II ${ }^{29}$. Przyczyną zaburzeń poznawczych jest często zakłócona przestrzeń ciszy.

W procesie kreowania słów za pomocą wyobraźni objawia się dynamiczny charakter ciszy. Umiejętność pracy w milczeniu, ciszy towarzyszy każdemu intelektualiście. Według Platona, myśl człowieka jest „«mową pierwszą» świata, natomiast treść zawarta w piśmie, danym do odczytania, jest «mową drugą» - cieniem lub widmem myśli" ${ }^{30}$. W ciszy znacznie lepiej pracuje wyobraźnia, a myśli są rzetelniej zapamiętywane. Stąd potrzeba, by od najmłodszych lat uczyć dziecko przebywania w ciszy ${ }^{31}$. Najprostszym sposobem nabycia tej umiejętności jest częste przebywanie w miejscach ciszy, na przykład na łonie natury, w świątyni, muzeum, bibliotece, która konstruktywnie wpływa nie tylko na rozwój galenosfery, ale także logosfery. W średniowieczu takim miejscem, szczególnie umiłowanym przez mnichów (franciszkanów, benedyktynów i cystersów), był ogród - paradicus claustralis. Niektóre zakony obowiązywała reguła milczenia i z tego względu szczególnie do 1250 r. tak planowano ogrody, by sprzyjały one modlitwie i wyciszeniu (altany, labirynt, odpowiednia roślinność - róże, bzy oraz zioła $)^{32}$. Nie tylko osoby duchowne były zachęcane do milczenia. Również promowane było ono na płaszczyźnie świeckiej, w życiu codziennym. Młode dziewczęta wychowywano do zachowania umiarkowania w mowie. Uczono je stonowanej, milczącej obecności w towarzystwie. Do podobnej wstrzemięźliwości zachęcano również młodych chłopców ${ }^{33}$.

Potrzebę ciszy u dziecka rozumiała Maria Montessori. Wychowane w hałasie, na przykład przy ciagle włączonym telewizorze, prowadzi je do nerwowości, niepokoju, a nawet agresji, dlatego pedagogów zachęcała do częstego przeprowa-

${ }^{28}$ Platon, Fajdros, 272 a, b.

${ }^{29}$ Wyrażenie Jana Pawła II ze spotkania z okazji 600-lecia Wydziału Teologicznego Uniwersytetu Jagiellońskiego w Krakowie 8 czerwca 1997 r.

${ }^{30}$ T. Kobierzycki, Cisza i milczenie wedtug Platona, w: K. Handke (red.), dz. cyt., s. 115.

${ }^{31}$ Por. A. Erkert, Dzieci potrzebuja ciszy, Kielce 2001. Książka prezentuje zabawy relaksujące, pomagające się odprężyć, wyciszyć, koncentrować na wykonywanym zadaniu.

${ }^{32}$ Por. G. Bobilewicz, Malarze ciszy i milczenia, w: K. Handke (red.), dz. cyt., s. 93.

${ }^{33}$ M. Stępień, dz. cyt., s. 99. 
dzania tzw. lekcji. Do grupy przedszkolaków przyniosła śpiące niemowlę, przedstawiając je jako „nauczyciela ciszy”. Dzieci, pragnąc je naśladować, zaczęły się „prześmigiwać” w zachowaniu spokoju i milczenia. Zachwycały się wtedy tym, że słychać oddech dziecka. Tak zrodził się pomysł na lekcję ciszy, podczas której przewidywane są tego typu zabawy ${ }^{34}$. Zadania te nie zawsze są proste dla dzieci, lecz z czasem zauważyć można dużą samodzielność w zachowaniu ciszy.

\section{Zakończenie}

Jak ukazano powyżej, cisza ma duży wkład w rozwój człowieka - psychiczny, duchowy, społeczny i kulturowy. Galenosfera, jednak - jak każda ludzka przestrzeń - narażona jest na zniekształcenia. Patologiczny charakter może mieć galenosfera człowieka skrajnie izolującego się od otoczenia. Na podstawie jego zewnętrznej obserwacji można stwierdzić, że jest to „człowiek ciszy”, a w rzeczywistości może się okazać, że jest wręcz przeciwnie - nie potrafi żyć z ludźmi, żyje w sprzeczności z sobą, nie akceptuje siebie, funkcjonuje w ogromnym wewnętrznym chaosie. Inną niepokojącą patologią ciszy jest to, że potrafi być ona także nośnikiem zła, a nawet narzędziem szatana. Szczególnie jest to zauważalne w praktykach okultystycznych i pseuomedycznych, uzdrowicielskich, technikach relaksu (joga) itd. Rozwój człowieka musi być pojmowany integralnie i dlatego rozwój mediosfery także musi mieć charakter integralny. Galenosfera, by właściwie dojrzewała, musi formować się całościowo, biorąc pod uwagę inne sfery człowieka - przestrzeń słowa, dźwięku i obrazu.

\section{Theological basis for education to galenosphere (Summary)}

The term of galenosphere designates the space of silence. Galenosphere, together with logosphere (the sphere of words), iconosphere (the sphere of pictures) and sonosphere (the sphere of sounds) creates mediosphere of the person. The pedagogical and teological interpretation of galenosphere was presented in the paper. The topic is still not described sufficiently, causing a lot of problems not only in theory, but also in practice. The conditions of contemporary lifestyle are unfavorable for practicing silence. Moreover, its marginalization is progressing. The same problem concerns also logosphere.

The need for silence was presented by biblical examples. They show that silence - as creative and very important part of human mediosphere - takes part in personal growth of human being. The development of logosphere, iconosphere and sonosphere are impossible without sonosphere.

${ }^{34}$ M. Montesorri, The Discovery of The Child, Delhi 2004, s. 124-128. 